\title{
The role of culture, consumption and community in cluster development: the case of Portland's athletic and outdoor industry, Oregon (USA)
}

\author{
Heike Mayer, Bern, Joseph Cortright, Portland
}

\section{Introduction}

The athletic and outdoor industry cluster in Portland is especially appropriate for a study about the role of consumption, culture and community in cluster emergence. The cluster consists of a group of innovative, world-class firms that design, market and distribute footwear, apparel and related gear for sports, recreation and active lifestyles. The cluster is anchored by three well known firms: Nike, Adidas and Columbia Sportswear. It has diversified beyond these three firms through entrepreneurial spinoff processes and firms moving to the region to be part of a growing and specializing cluster. Portland's cluster may be described as a so-called «alpha cluster» (SCHOALES 2006), meaning that it is characterized by rapid innovation and product cycles, tight geographic concentrations and relatively high wages. Most importantly, alpha cluster industries such as Portland's athletic and outdoor sectors are characterized by the premium firms place on product novelty and rapid product introduction. Because the industry relies heavily on new product development, it illustrates how place-based characteristics, a region's community and its users may influence learning and innovation. As Molotch argues,

«goods contain - in the detail of their fabrication and outcome - the places of their origin. Products can be tracers of the nature of the places they come from» (2002: 665).

Thus Portland's athletic and outdoor industry may serve well for an inquiry into the role of community and culture in cluster development.

Indeed Portland's athletic and outdoor firms belong to a very dynamic and constantly changing industry. Like the fashion industry, firms have to respond to rapidly changing consumer tastes and demands. Leading firms also use frequent style changes to differentiate their products from low cost imitators. Because styles generally lack intellectual property protection, it is relatively easy for competitors to copy them; by continually developing new styles leading firms insulate themselves from this kind of competition. It is also a highly competitive industry in which firms not only compete based on brand recognition and image but also on product performance and material quality. In addition, symbolic values play an important role as sportswear and gear express and represent unique lifestyles and imaginations (HaUge 2011). Apparel is, by definition, conspicuous consumption, and in social settings, humans use clothing to signal status, group identity, and interests. Athletic and outdoor gear users are key to this industry's success as they test, develop and pioneer products (BRÅTA et al. 2009). These users can be divided into different types of innovators. Most studies have focused on the role of the so-called lead user - users who are at the cutting edge of trends and who expect benefits from product improvements in innovation processes (BALDWIN, HIENERTH \& VON Hippel 2006; von Hippel 1988). Yet there are other types of users that are important for this industry, including those who work inside athletic and outdoor firms and who not only use the products on a daily basis but also improve them. BRÅTA et al. (2009) have referred to these users as the «passionate insiders» and they define them as

«employees who are especially engaged or passionate about sports activities that are relevant for the products or goods produced by the firm» (p. 38).

These employees are part of a community of practice that extends beyond the firm that employs them. They are embedded in a unique social and regional context, they are part of a specific production system and they are consumers (and as such innovators) of the products they help produce. In short they are citizens and consumers, as well as being workers. Their role as workers, embedded in a particular firm, may be less salient, and shorter-lived than their other roles. As such, these multiple roles and connections all influence the ways in which clusters emerge and grow. In this article, the focus is on the specific environment in which workers of Portland's athletic and outdoor industry are embedded. It is argued that the local environment and community exert its influence primarily through labor market pooling on the cluster's development.

The geographic center of this industry is in the Portland metropolitan area. Located about three hours south of Seattle and eleven hours north of San Francisco, Portland is a mid-sized city of about 2.2 million residents. Compared to other cities, Portland has the highest concentration of firms in this industry and Oregon accounts for the single largest share of footwear-related patents in the United States. The region is well-known for its innovative and sustainability-oriented urban and regional planning policies (Аввотт 1983, 2001; OzAWA 


\begin{tabular}{|l|r|r|r|r|r|r|r|r|}
\hline & $\mathbf{2 0 0 1}$ & $\mathbf{2 0 0 2}$ & $\mathbf{2 0 0 3}$ & $\mathbf{2 0 0 4}$ & $\mathbf{2 0 0 5}$ & $\mathbf{2 0 0 6}$ & $\mathbf{2 0 0 7}$ & $\mathbf{2 0 0 8}$ \\
\hline Firms & 760 & 766 & 757 & 740 & 776 & 820 & 824 & 822 \\
\hline Employment & 12,629 & 12,525 & 13,221 & 13,807 & 14,190 & 14,371 & 14,026 & 14,100 \\
\hline Payroll (in millions) & $\$ 646$ & $\$ 685$ & $\$ 804$ & $\$ 972$ & $\$ 1,012$ & $\$ 1,057$ & $\$ 1,112$ & $\$ 1,166$ \\
\hline Average Wage & $\$ 51,100$ & $\$ 54,700$ & $\$ 60,800$ & $\$ 70,400$ & $\$ 71,300$ & $\$ 73,500$ & $\$ 79,300$ & $\$ 82,700$ \\
\hline Location Quotient & 1.10 & 1.21 & 1.36 & 1.48 & 1.57 & 1.60 & 1.59 & 1.66 \\
\hline
\end{tabular}

Tab. 1: Firms, employment, payroll and wages for athletic and outdoor firms in Oregon, 2001-2008 Firmen, Beschäftigung, Löhne und Gehälter in der Sport- und Outdoor-Industrie in Oregon, 2001-2008 Entreprises, emploi et salaires dans l'industrie du sport et des activités de plein air de l'Oregon, 2001-2008 Source: BuREAU of LABOR STATISTICS

2004). Already in the 1970s Oregon passed laws that would limit urban growth and development and the state initiated many innovations that would encourage compact urban development (Аввотт 1983; OzaWa 2004). Today Portland is a very attractive and livable city especially for young and mobile Americans who are interested in alternative lifestyles and sustainable living. As a result, a unique community culture and associated economy emerged. Portland has become known for its culture that is outdoor-oriented, ecofriendly and which also has a strong presence in the artisan economy (HeyING 2010). Besides traditional export industries such as high-technology, there are numerous small and medium sized firms that produce artisanal products such as beer, specialty food, coffee, distilled spirits, independent music and magazines, but also bikes and fashion. Particularly the artisan economy around bikes and fashion has benefitted not just from innovative artisans and producers, but also from venturesome users and customers. In Portland, there is a strong do-it-yourself (DIY) culture and a business ethos that emphasizes uniqueness and authenticity. Firms like Nike, Adidas or Columbia - though very corporate in nature - benefit from this culture, particularly, it seems, through the creation of a creative milieu that helps give employees and entrepreneurs in the more mainstream athletic and outdoor industry a competitive edge.

\section{Case study region}

Oregon's athletic and outdoor industry cluster consists of more than 800 firms that directly employ 14,100 workers. The athletic and outdoor industry cluster is defined in this article as a set of firms that design, market and distribute footwear, apparel and related gear for sports, recreation and active lifestyles. To identify core aspects of the cluster, eight NAICS industry codes were selected: NAICS 315 Apparel Manufacturing, 3162 Footwear Manufacturing, 33992
Sporting and Athletic Goods Manufacturing, 42391 Sporting and Recreational Goods and Supplies Merchant Wholesalers, 4243 Apparel, Piece Goods and Notions Merchant Wholesalers, 5314 Specialized Design Services, 3322 Cutlery and Handtool Manufacturing, 336991 Motorcycle, Bicycle, and Parts Manufacturing. However, it should be emphasized that while these NAICS codes capture the largest firms and the majority of the economic activity directly associated with the core of the cluster, they do not capture firms, suppliers, service providers and others that are also active in the industry (i.e. for example public relations firms, human resources staffing companies). Total statewide payroll in 2008 was nearly 1.2 billion and the average wage stood at $\$ 82,700$ according to data from the Bureau of Labor Statistics (see also Table 1). In addition more than 3,200 self-employed persons work in closely related fields, like specialized design services (CORTRIGHT 2010).

The industry started to emerge in Oregon with the founding of Nike in 1964. Initially, Nike was known as Blue Ribbon Sports and its founders imported Japanese running shoes before they developed their own innovative shoe design (Moore 2006). The Nike founders created a set of products (high performance athletic shoes) and a business model (global branding of footwear), that dramatically changed the apparel and footwear industries. Historically, there was little reason to believe that footwear firms would flourish in Portland; while the region had a few makers of outdoor related footwear (e.g. Danner and some other smaller firms were making boots for logging, construction and hiking), the nation's footwear industry was historically concentrated in New England, St. Louis and Akron, Ohio (Sorenson \& Audia 2000). Nike played a leading role in the growth of the cluster, particularly in bringing other firms to the region and creating spinoffs. For example, in 1987 former Nike employees Rob Strasser and Peter Moore spun off their own firm in Portland with the name Sports 


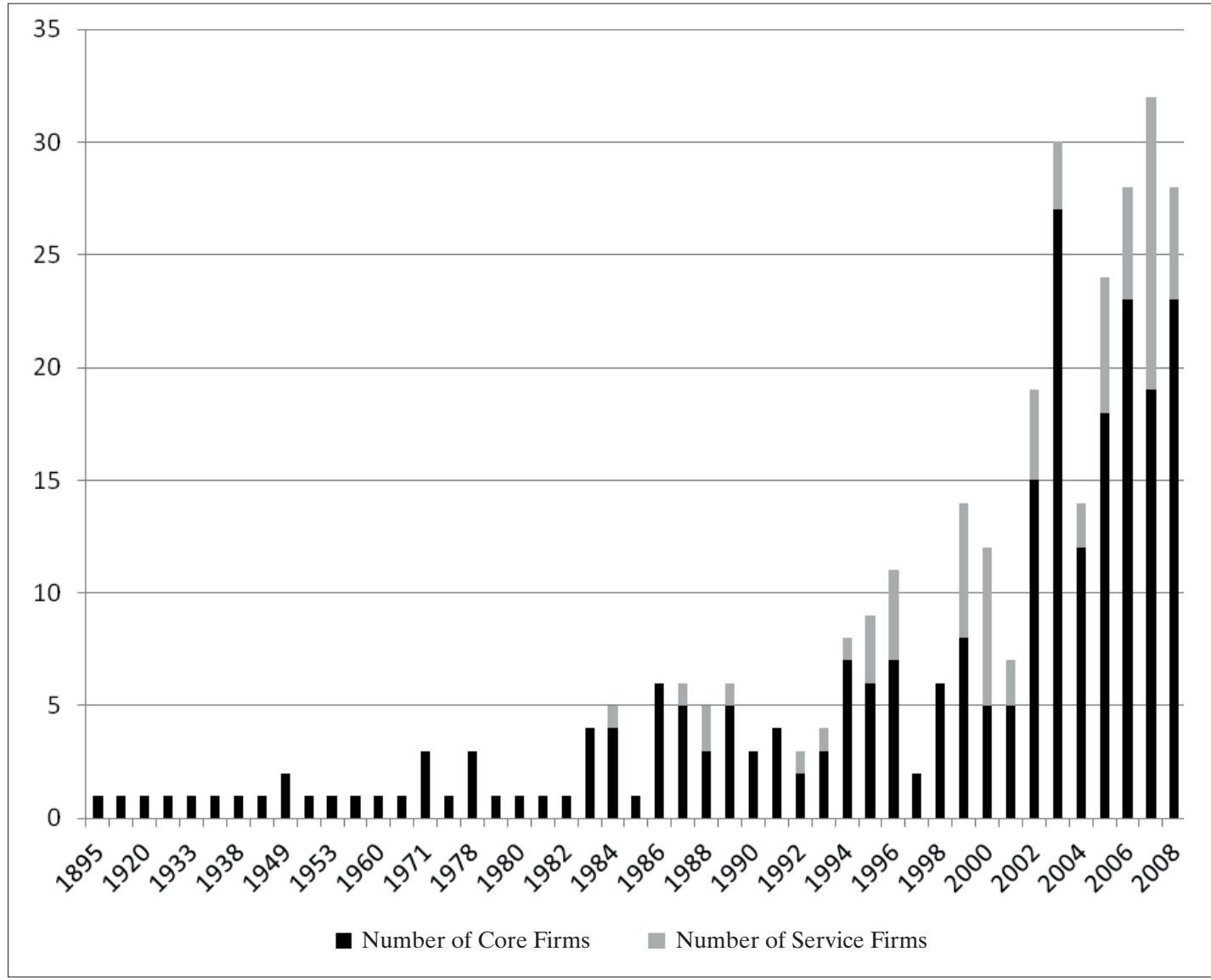

Fig. 1: Company emergence in Portland, Oregon, 1895-2009

Die Entwicklung der Firmen in Portland, Oregon, 1895-2009

Evolution du nombre d'entreprises à Portland, Oregon, 1895-2009

Source: PDC company directory and authors' research

Inc. and they started to work for Nike's competitors, including Adidas. Strasser and Moore were responsible for bringing Adidas North American headquarters to Portland and played key roles in updating the company's organization and global strategy in the early 1990s (SMIt 2005).

Yet, Portland's cluster is not a typical hub-and-spoke industrial district that is centered on a few large firms (Gray, Golob \& Markusen 1996). While there are some professional service firms (particularly in media and advertising) that have strong connection to hub firms, smaller firms in the industry are often independent of the large anchor firms, typically selling into niche markets too small to interest the larger firms. Over time the cluster not only added core firms (those firms that work on athletic and outdoor products directly) but also a range of specialized service providers such as freelance designers, public relations agencies, and human resource firms. Figure 1 illustrates the evolution of the 340 firms for which founding year information was available.

\section{Methodology}

Methodologically, use is made here of a variety of data sources and mixed methods. The study is based on an online survey of 368 firms of which 80 (21.7\%) responded. The survey was conducted in February 
2010. The survey responses were compared to the survey population. It may be assumed that the survey is representative of the athletic and outdoor industry cluster in terms of firm age as well as firm specialization. The survey included questions about firm history, the geography of business partners, and interactions with local consumers/users. In addition to the survey, several focus groups (on topics such as human resources, startups and entrepreneurship) and key expert interviews were conducted during spring 2010. The study was conducted as part of a broader regional effort that was coordinated by Portland's major economic development agency, the Portland Development Commission.

\section{Cluster organization and the role of users and consumers}

Portland's athletic and outdoor industry is characterized by a global division of labor. Most large firms in the cluster outsource their manufacturing activities to low-cost locations in Asia. Some smaller niche firms engage in domestic manufacturing. Portland's competitive advantage, however, lies in the concentration of activities that are critical for product design, performance and marketing. Companies like Nike and Adidas manufacture a vast majority of their apparel and footwear products in Asian countries and they engage in complex transnational supply chains (DonAGHU \& BARFF 1990; Locke 2002). Nike, for example, started off in the 1970s selling shoes made in Japan. In the later 1970s and 1980s it shifted manufacturing to suppliers in Korea and Taiwan, and then to China. Over the past decade Vietnam and Indonesia have become increasingly important manufacturing locations. Asian production, which is one of Nike's initial innovations, is now a common industry practice. In 2008, Columbia Sportswear had $67 \%$ of its apparel and $99 \%$ of its footwear manufactured in China and Vietnam (Columbia Sportswear 2009). Nike's focus on product development, image and marketing and its outsourcing strategy to low-cost countries is exemplary for transnational firms in this industry. These strategies have also elicited critique, particularly in regards to problematic labor conditions and environmental problems among others (KLEIN 2000) (Tab. 2).

For large firms, there are a few key exceptions to the general tendency to manufacture products in Asia due to the need to protect proprietary information and technology. Nike, for example, manufactures its Air-Sole cushioning material and components at its company-owned Nike IHM Inc. facility located in Beaverton, Oregon, and in St. Charles, Missouri (NIKE 2011). A few firms - those that focus on highly specialized or customized products - specialize in domestic

\begin{tabular}{|l|c|}
\hline Country & Share of Production \\
\hline China & $36 \%$ \\
\hline Vietnam & $36 \%$ \\
\hline Indonesia & $22 \%$ \\
\hline Thailand & $6 \%$ \\
\hline
\end{tabular}

Tab. 2: Location for production of Nike footwear, 2009 Die geographische Verteilung der Produktion von Nike Schuhen, 2009

Répartition géographique de la production de chaussures Nike, 2009

Source: NiKe AnNual Report 2009

manufacturing and they have a significant manufacturing presence locally. For example, Leatherman manufactures and assembles its tools and knives in Portland. Kialoa manufactures the bulk of its paddles in Central Oregon. Local bicycle gear and frame makers, like Chris King Precision Components, manufacture their products locally.

Both large and small firms, however, benefit from the concentration of their activities in design, product development, and marketing. Portland-based employees develop and test new products, Portland-based marketing experts create global branding campaigns and supply chain experts manage global production activities. There are several reasons why these activities are concentrated in Portland. Design, for example, is the key differentiator among athletic and outdoor firms. These firms develop products to meet the specific technical needs of end users as well as the tastes of different consumer groups. Product design and development is usually a collaborative process integrating designers, marketing experts and those responsible for managing manufacturing and supply chains. Rapid and continuing changes to product designs are an important competitive factor. Because it is difficult to accurately forecast consumer demand, speed and flexibility in responding to the market are critical. Adidas reports using fast turnaround design techniques at its Portland location to reduce the amount of time needed to produce new products. The need to cooperate with critical business partners is another reason why firms benefit from co-location. Keen Footwear, for example, relies mostly on free-lance designers and consultants and values the availability of this specialized labor pool.

The survey confirms this geographic pattern. When asked about the location of business partners that firms have cooperated with on activities that led to new products or modifications of existing products, a bifurcated geographic pattern emerged: The majority 


\begin{tabular}{|c|c|c|c|c|c|c|c|c|c|}
\hline & Portland & $\begin{array}{c}\text { OR \& } \\
\text { WA State }\end{array}$ & $\begin{array}{l}\text { United } \\
\text { States }\end{array}$ & $\begin{array}{c}\text { Latin } \\
\text { America }\end{array}$ & Europe & $\begin{array}{c}\text { Asia } \\
\text { Pacific }\end{array}$ & Other & $\begin{array}{c}\text { Not } \\
\text { relevant }\end{array}$ & Valid N \\
\hline $\begin{array}{l}\text { Internal R\&D } \\
\text { and design units }\end{array}$ & $65.6 \%$ & $12.5 \%$ & $20.3 \%$ & $3.1 \%$ & $17.2 \%$ & $20.3 \%$ & $4.7 \%$ & $18.8 \%$ & 64 \\
\hline $\begin{array}{l}\text { Suppliers of } \\
\text { materials, } \\
\text { services, } \\
\text { equipment }\end{array}$ & $35.9 \%$ & $29.7 \%$ & $54.7 \%$ & $6.3 \%$ & $25.0 \%$ & $46.9 \%$ & $1.6 \%$ & $9.4 \%$ & 64 \\
\hline $\begin{array}{l}\text { Customers and } \\
\text { users }\end{array}$ & $58.7 \%$ & $54.0 \%$ & $85.7 \%$ & $7.9 \%$ & $36.5 \%$ & $22.2 \%$ & $15.9 \%$ & $7.9 \%$ & 63 \\
\hline Manufacturers & $26.6 \%$ & $20.3 \%$ & $31.3 \%$ & $4.7 \%$ & $15.6 \%$ & $59.4 \%$ & $1.6 \%$ & $14.1 \%$ & 64 \\
\hline $\begin{array}{l}\text { Other firms in } \\
\text { your industry }\end{array}$ & $52.8 \%$ & $41.5 \%$ & $47.2 \%$ & $0.0 \%$ & $18.9 \%$ & $18.9 \%$ & $3.8 \%$ & $26.4 \%$ & 53 \\
\hline Consultants & $50.9 \%$ & $17.5 \%$ & $24.6 \%$ & $0.0 \%$ & $8.8 \%$ & $5.3 \%$ & $3.5 \%$ & $31.6 \%$ & 57 \\
\hline $\begin{array}{l}\text { Commercial labs } \\
\text { or private } R \& D \\
\text { institutes }\end{array}$ & $16.3 \%$ & $8.2 \%$ & $18.4 \%$ & $0.0 \%$ & $10.2 \%$ & $14.3 \%$ & $2.0 \%$ & $\mathbf{5 1 . 0} \%$ & 49 \\
\hline $\begin{array}{l}\text { Universities or } \\
\text { higher education } \\
\text { institutions }\end{array}$ & $28.6 \%$ & $18.4 \%$ & $24.5 \%$ & $0.0 \%$ & $6.1 \%$ & $8.2 \%$ & $0.0 \%$ & $42.9 \%$ & 49 \\
\hline
\end{tabular}

Tab. 3: Geography of business partners

Survey question: «Please think of partners you've cooperated with on activities that led to new products or modifications of existing products. Please indicate the primary location of those business partners during the last three years, 2007 to 2009 (please check all that apply).»

Die Geographie der Firmenpartner

Géographie des partenaires commerciaux

Source: Portland Athletic and Outdoor Gear Industry Survey, 2010

of activities related to product development and associated interactions with important business partners such as consultants, other firms in the industry, etc. are located in the Portland region while manufacturing takes place in the Asia Pacific region. $65.5 \%$ of the firms participating in the survey indicated that activities with their internal $R \& D$ and design units take place in the Portland region. More than half of the firms $(50.9 \%)$ noted that the consultants they work with are also located in the Portland region. $52.8 \%$ of the firms indicated that other firms in their industry that they cooperate with are co-located in the Portland region.

Most striking, however, is the importance these firms place on interactions with customers and users. 58.7\% of the firms responding to this question indicated that they cooperated with Portland-based users/customers on new product development and modifications of existing products. In general, firms in the athletic and outdoor industry seem to rely heavily on US-based customers and user (Tab. 3).

Survey respondents were asked about the importance of interactions with local users/consumers in the development of products. Figure 2 illustrates the responses. More than half of the respondents (54\%) note that involvement of local users/consumers in visual design and styling of the products is extremely important (with an additional $25.4 \%$ noting it was somewhat important). In addition, more than half of the respondents regard engagement of users/consumers in brand image and users' feedback on product concept and prototype as extremely important $(50.8 \%$ for each category). For $47.6 \%$ of respondents engaging local users/consumers in testing products is extremely important (with an additional 25.4\% noting this interaction as somewhat important). Somewhat less important is the engagement of users/consumers in innovative activities related to suggestions and ideas for new applications as well as material development and improvement.

These results indicate the importance of local users and consumers particularly in the visual and performance related aspects of the products this industry develops. Portland's athletic and outdoor cluster shows a strong pattern of user innovation similar to other types of sports equipment industries (HAUGE 2011; Hienerth 2006; LÜthJe, Herstatt \& von Hippel 2005). Outdoor and athletic gear represents a market that is influenced by highly demanding and competent customers, who often modify their products, as well as short product cycles that are sensitive to changing 


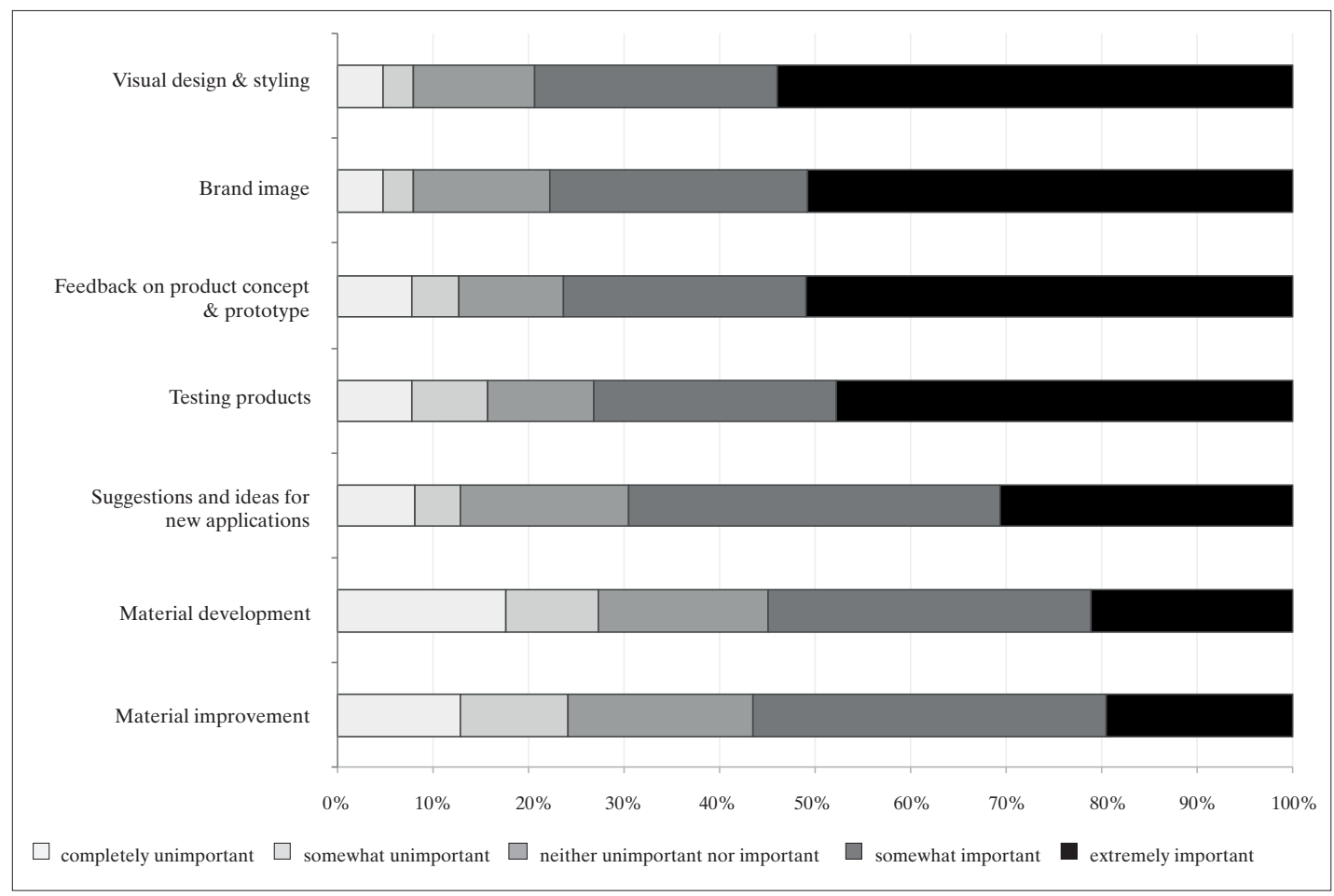

Fig. 2: Interactions with local users/consumers

Survey question: «How important are each of the following interactions with local users/consumers to your company's development of products (please choose one rating in each row)?»

Interaktionen mit lokalen Nutzern und Konsumenten

Interactions avec les utilisateurs locaux et les consommateurs

Source: Portland Athletic and Outdoor Gear Industry Survey, 2010

user and consumer demands and tastes. In addition, the industry not only sells products that perform well but also products that are associated with intangibles such as styles and fashion. Knowing what users/customers want and need is key to the industry's competitiveness.

\section{Unique aspects of Portland's culture and community}

Local users and consumers are important to the industry's efforts to develop new products, and the Portland region provides an ideal environment for demanding and competent users/consumers. Compared to the average for the United States, Portland residents are twice as likely to go camping, $60 \%$ more likely to go hiking or backpacking, and $40 \%$ more likely to play golf or hunt (CORTRIGHT 2002). The region also ranks last in theme park attendance, lowest in sedentary life styles and second highest in vigorous physical activity. CORTRIGHT notes that distinctive behaviors and tastes influence a region's economy, particularly through local demand for goods and services. In the case of the outdoor and athletic industry, users and consumers in the Portland region are different from those in other regions in the United States. They are more active and sporty and as such their tastes and preferences influence their demand for local athletic and outdoor products. For example, Nike was started in Eugene, Oregon, which at the time was one of the regions that pioneered jogging during its boom period in the 1970s. This in turn influenced Nike's success in developing running shoes that were popular with local users. Early Nike employees were hired locally from among the ranks of local athletes, and many key product design decisions were based on the direct experience of these athletes/workers. 
In addition to the influence of consumer tastes on the demand side, similar distinctive patterns shape the supply side. CORTRIGHT notes that

«distinctive attitudes influence the supply of goods and services. The existing base of industries and workers (and their collective knowledge and skills) will influence the set of goods and services that local firms produce. The interests and preferences of local entrepreneurs will influence the set of firms that are started. Hobbies become businesses» (CORTRIGHT 2002: 11).

Several firms in the cluster were started up by such «passionate insiders» (BRÅTÅ et al. 2009) who turned their hobbies into businesses. A typical example of user-led innovation is Leatherman Tool. Portlander Tim Leatherman traveled across Europe in an aging Fiat, which constantly needed minor repairs and adjustments. He hit upon the idea for a simple folding tool that would incorporate screwdrivers, a knife blade, and pliers in a form that could be carried anywhere. The company website invites users to contribute stories of how they have used their Leatherman tools to solve unusual problems, and highlights the best story each month. Other companies have similar creation stories based on the insights from practical experience: Bend-based Ruffwear made its first product, a collapsible dog-dish for hikers, after seeing a friend struggle to share water out of a canteen with her dog. The region's bicycle frame makers sell a large portion of their output to local customers, and the city's reputation as a hotbed of bicycling enables firms to sell to a wider national market. New and customized designs - like the one-off bike-bar built by Metrofiets for Hopworks Organic Brewery - are the product of imaginative and unusual interactions between customers and producers and reach even into Portland's artisanal economy (Foyston 2009).

In Portland, it is common for employees of athletic and outdoor gear firms to also be the innovative users who come up with new ideas. Companies hire employees from the local base of users, many of them passionate participants in recreational activities, because they are able through their activities to potentially identify customers for their products. While actual cases of involvement of workers/consumers in the design process were not examined here, the focus groups give insight into the ways in which the local environment shapes how workers balance recreation and therefore the use of products with their productive engagement with the firms. In other words, the workers in the industry value athletic activities and outdoor recreation and take time for this. This in turn makes it possible for them to incorporate experiences they gain from these activities into their work processes. Portland is considered a good place to test products. Workers are also seen as atypical, i.e. they do not insist on traditional employment patterns and 9-to-5 jobs. Rather, workers «love and live their products», as one focus group participant noted. The support for work-life balance in the community generally, and in athletic and outdoor firms in particular, means that the boundaries between work and play, making and using, producer and user are less clear-cut than they are in other industries. Many of the user-based innovations in firms are the product of insights from employees using the products their companies produce.

The essential characteristics of the cluster - active living and outdoor recreation - are a reflection of the values and interests of Oregonians. A key part of the cluster's competitive advantage stems from the environment that Oregon provides to the people in this industry to live and work in what some in the industry call a «hybrid lifestyle.» The region's great environment, abundant recreational opportunities, and widespread sustainability ethic attracts and helps root the kinds of workers who help the industry flourish. The connection to place is an essential part of firm strategy and innovation. Leatherman, for example, is explicit about the relationship between place, its employees, and the ideas behind its products.

As focus group and interview participants indicated, the kind of people who value this casual/active lifestyle and blended work-recreation balance are more likely to be found in Portland, and Portland is an attractive place for people with these interests. Embeddedness (Granovetter 1985) in this milieu reinforces the shared values of these workers, and is consistent with the firm's interests. Firms are competing for talent in this environment and have to offer employees opportunities consistent with these values in order to attract and retain the best workers.

One of the segments of this cluster exhibits the connection with place especially well. The bicycle industry has deep roots in Portland. In the 1970s, lawmakers in Oregon and in Portland began to encourage car-free transportation (for example, the Oregon Bicycle Bill that was passed in 1971 mandates that 1 percent of the transportation funds are used for bike and pedestrian infrastructure). Many Portlanders cycle and the industry benefits from this strong culture. Framemakers have a strong connection to the place and the community and they often put «handcrafted in Portland» or «handmade with love and fury in Portland, Oregon» on their frames (SMith \& Wineman 2010: 118). One bicycle maker is quoted saying that eventually,

«people will come to Portland for a bicycle, much like they would go to Switzerland for a watch or to Milan for a suit» (Smith \& Wineman 2010: 118-119). 
SMITH and Wineman highlight the strong networks and connections among this sector's participants and say that

«bicyclists involved in business, recreation, and advocacy interact with each other in a dense and overlapping network of social connections where people share support, information, and even passion about politics, social initiatives and the environment» (2010: 120).

Portland's unique place-based characteristics and the distinctive tastes and behaviors of its residents provide a fertile seedbed for the athletic and outdoor industry. It is the specialized labor pool that not only provides the critical talent base to firms but also serves as a unique source of innovation. As a result, the cluster benefits from blurring boundaries between work and active/social life.

\section{Conclusion}

This paper describes Portland's athletic and outdoor gear cluster and the role of place-based characteristics and the community in maintaining the cluster's competitiveness. So-called «passionate insiders» are a critical component in the success of Portland-based athletic and outdoor gear firms. «Passionate insiders» are employees or entrepreneurs who use the products and as a result provide important feedback about the product's performance. The environment in which these passionate insiders live and work is critical because it facilitates their creative endeavors. Portland's and Oregon's unique place-based characteristics as well as the specific tastes and behaviors of its residents facilitate the creation of a unique community of employees/entrepreneurs/users that help keep the industry on the cutting edge. Living in a place where these same people can indulge their passions outside the firm - in a rich recreational environment, where a balanced lifestyle is an accepted norm - makes it easier for firms to attract and retain workers with the skills and outlook best suited to this industry.

The cluster benefits from embeddedness of human capital in place. Talented people in the industry often progress through a variety of roles with different firms (e.g. designer or product manager at a large firm), learning the ropes, and then going to work for or starting a smaller firm, utilizing the skills and insights learned at the larger firm. Also, a large fraction of the people in this industry appear to embrace its core value proposition about work-life balance, and consequently highly value the opportunities for recreation locally. Portland's labor market agglomeration advantage stems from the combination of these factors: multiple firms with career advancement oppor- tunities, chances for entrepreneurship, and a great work-life balance.

The primary purpose of this article is to highlight the role a community plays for the competitiveness of the industry. By community reference is not only made to the economic aspects of the cluster (such as the business relationships or the infrastructure) but - maybe more importantly - the unique social, cultural and contextual aspects of a place. As Mоцотсн (2002) argues, products reflect the unique aspects of a place and the ways in which designers, users, producers and other cluster participants interact in situ matters in terms of the shape and feel of a product. MоLотсH notes that

«products depend on just how the expressive, the material, and the organizational elements connect in a given place at a given time. People breathe in their industrial atmosphere through stories, jokes, manners, architecture, street styles, sounds, odors and modes of maintenance that surround, as well as what they remember and what they anticipate» (2002: 685-686).

Molotch's (2002) insights are echoed by the argument of GlaEsER et al. (2001) about the «consumer city». Cities provide not just production advantages, but also advantages in consumption as well. People in athletic and outdoor gear industries have a significant and disproportionate interest in outdoor recreational opportunities, and there are strong complementarities between the presence of these firms and the availability of these opportunities. This is expressed in the notion of the industry that it is easy to attract talented people to Portland because of both the concentration of firms and the great cultural fit between the place and the industry.

The literature on clusters has not appeared to have paid due attention to the nexus between community and employees/entrepreneuers/users and the role their embeddednesss in place plays in the emergence and growth of clusters. Most studies have focused on the ways in which cluster actors organize their production and these studies have provided insights into the role of inter-firm networks in innovation and competitiveness of cluster firms (BraczyK, Cooke \& HeIDenreich 1998; Piore \& SAbel 1984; Porter 2000). A second set of studies has started to analyze the ways in which the urban environment facilitates creativity and innovation (FlORIDA 2002; GlAESER et al. 2001). However, these latter studies have been criticized for not paying attention to the ways in which the economic geography of production influences urban and regional development (STORPER \& SCOTT 2009). A third set of studies - those most relevant for this article - have focused on the role of communities of users/ customers in industry innovation (AMIN \& ROBERTS 
2008; Di Maria \& Vladi 2008; Grabher et al. 2008). The community of users/consumers in the case of Portland's athletic and outdoor gear industry consists of employees and entrepreneurship who function as passionate insiders. They transmit ideas about product style and utility and are therefore critical innovation agents. Further studies should focus on the ways in which these passionate insiders influence innovation processes and how their work-life balance contributes to the bottom-line of the cluster. Furthermore, more insights need to be gained on the role of the local community and the ways in which uniqueness and distinctiveness of a place can facilitate cluster emergence. This is particularly important as policymakers could leverage such place-based community characteristics and develop policies around using place characteristics for economic development purposes.

\section{References}

Аввотт, C. (1983): Portland. Planning, politics, and growth in a twentieth-century city. - Lincoln: University of Nebraska Press.

Аввотт, C. (2001): Greater Portland. Urban life and landscape in the Pacific Northwest. - Philadelphia: University of Pennsylvania Press.

Amin, A. \& J. Roberts (2008): Knowing in action. Beyond communities of practice. - In: Research Policy 37, 2: 353-369.

Baldwin, C., Hienerth, C. \& E. von Hippel (2006): How user innovations become commercial products. A theoretical investigation and case study. - In: Research Policy 35, 9: 1291-1313.

BraczyK, H.-J., Cooke, P. \& M. Heidenreich (1998): Regional innovation systems. The role of governance in a globalized world. - London: UCL Press.

BrÅtÅ, H.O., Hagen, S.E., Hauge, A., Kotro, T., OrrenmaA, M., Power, D. \& P. Repo (2009): Users' role in innovation processes in the sports equipment industry - experiences and lessons. - http://www.nordicinnovation.net/_img/07028_users_role_in_innovation_processes_in_the_sports_equipment_industry_ final_report_web.pdf 23.01.2011.

Columbia Sportswear (2009): 10-K Annual Report. - http://investor.columbia.com/secfiling.cfm?filingID= 1193125-09-41147 02.02.2011.

Cortright, J. (2002): The economic importance of being different: regional variations in tastes, increasing returns, and the dynamics of development. - In: Economic Development Quarterly 16, 1:3-16.

CoRtright, J. (2010): The athletic and outdoor industry cluster: a white paper. - Portland, OR: Impresa Inc. Di Maria, E. \& F. Vladi (2008): Communities of consumption and made in Italy. - In: Industry and Innovation 15, 2: 179-197.

Donaghu, M. \& R. BarfF (1990): Nike just did it. International subcontracting and flexibility in athletic footwear production. - In: Regional Studies 24, 6: 537 552.

Florida, R. (2002): The rise of the creative class and how it's transforming work, leisure, community and everyday life. - New York: Basic Books.

Foyston, J. (2009): The Metrofiets/Hopworks Bike Bar rollout. - http://blog.oregonlive.com/thebeerhere/ 2009/09/the_hub_barbike_rollout.html 04.02.2011.

Glaeser, E.L., Kolko, J. \& A. Saiz (2001): Consumer city. - In: Journal of Economic Geography 1, 1:27-50.

Grabher, G., Ibert, O. \& S. Flohr (2008): The neglected king. The customer in the new knowledge ecology of innovation. - In: Economic Geography 84, 3: 253-280.

Gray, M., Golob, E. \& A. Markusen (1996): Big firms, long arms, wide shoulders. The «hub-and-spoke» industrial district in the Seattle Region. - In: Regional Studies 30, 7: 651-666.

GranovetTer, M. (1985): Economic action and economic structure: the problem of embeddedness. - In: American Journal of Sociology 91, 3: 481-510.

Hauge, A. (2011). Sports equipment. Mixing performance with brands. The role of consumers. - In: PIKE, A. (ed.): Brands and branding geographies. - Cheltenham, MA: Edward Elgar Publishing: 91-106.

Heying, C. (2010): Brew to bikes: Portland's artisan economy. - Portland, OR: Ooligan Press.

Hienerth, C. (2006): The commercialization of user innovations. The development of the rodeo kayak industry. - In: R\&D Management 36, 3: 273-294.

HIPPEL, E. vON (1988): The sources of innovation. Oxford: Oxford University Press.

KLEIN, N. (2000): No logo. Taking aim at the brand bullies. - Toronto: Knopf.

LOCKE, R. (2002): The promise and perils of globalisation. The case of Nike. - http://kms1.isn.ethz.ch/ serviceengine/Files/ISN/29550/ipublicationdocument_singledocument/42D57B34-8EC9-4E5B-B95A9B7726B033F1/en/2002-007.pdf 01.12.2009.

Lüthje, C., Herstatt, C. \& E. von Hippel (2005): Userinnovators and «local» information. The case of mountain biking. - In: Research Policy 34, 6: 951-965.

Molotch, H. (2002): Place in product. - In: International Journal of Urban and Regional Research 26, 4: 665-688.

Moore, K. (2006). Bowerman and the men of Oregon. The story of Oregon's legendary coach and Nike's cofounder. - Emmous, PA: Rodale.

NIKE IHM (2011): About us. - http://www.nike.com/ nikeihm/index.shtml 26.11.2011.

Ozawa, C. (2004): The Portland edge. - Washington D.C.: Island Press.

Piore, M. \& C. Sabel (1984): The second industrial divide: possibilities for prosperity. - New York: Basic Books.

Porter, M. (2000): Location, competition, and economic development: local clusters in a global economy. - In: Economic Development Quarterly 14, 1:15-34. 
SchoAles, J. (2006): Alpha clusters. Creative innovation in local economies. - In: Economic Development Quarterly 20, 2: 162-177.

Smit, B. (2005): Drei Streifen gegen Puma. Zwei verfeindete Brüder und der Kampf um die Weltmarktführerschaft. - Frankfurt am Main: Campus Verlag.

Smith, O. \& B. Wineman (2010): Bikes. - In: Heying, C.: Brew to bikes: Portland's artisan economy. - Portland, OR: Ooligan Press: 107-124.

Sorenson, O. \& P.G. Audia (2000): The social structure of entrepreneurial activity. Geographic concentration of footwear production in the United States, 1940-1989. - In: American Journal of Sociology 106, 2: 424-461.

Storper, M. \& A. ScotT (2009): Rethinking human capital, creativity and urban growth. - In: Journal of Economic Geography 9, 2:147-167.

Summary: The role of culture, consumption and community in cluster development: the case of Portland's athletic and outdoor industry, Oregon (USA)

In recent years, economic geographers have begun to consider the role of users and consumers in innovation processes. Users are seen as «reflexive actors» (Grabher, Ibert \& Flohr 2008) who influence product development. Yet the literature on user innovation does not consider the role of user and consumer communities as seedbeds for cluster emergence. More specifically, it appears that literature has paid insufficient attention to the role of employees and entrepreneurs as users/consumers embedded within a specific context, as well as to the ways in which an industry cluster co-evolves with a region's distinctive social and cultural characteristics. This article examines the role of a region's culture, consumption patterns and community characteristics in cluster development. In particular, it presents preliminary results from a study of the athletic and outdoor industry in Portland, Oregon (USA).

Keywords: user innovation, cluster emergence, athletic and outdoor industry

\section{Zusammenfassung: Die Rolle von Kultur, Konsum und Kontext in der Cluster-Entwicklung: die Sport- und Outdoor-Industrie in Portland, Oregon (USA)}

In den letzten Jahren haben Wirtschaftsgeographen damit begonnen, die Rolle von Nutzern und Verbrauchern in Innovationsprozessen zu berücksichtigen. Nutzer, Kunden, Verbraucher werden als «reflexive Akteure» gesehen (GrabHer, IBERT \& Flohr 2008), die die Entwicklung von Produkten und Dienstleistungen grundlegend beeinflussen. Allerdings vernachlässigt diese Literatur die Rolle der Nutzer innerhalb eines bestimmten regionalen Kontexts und deren Einfluss auf die Cluster-Entwicklung. Dieser Artikel untersucht die Bedeutung spezifischer Kultur-, Konsumund Community-Eigenschaften einer Region und deren Einfluss auf die Entstehung und das Wachstum eines Clusters. Konkret werden erste Ergebnisse einer Studie der Sport- und Outdoor-Industrie in Portland, Oregon (USA), vorgestellt.

Schlüsselwörter: nutzerinduzierte Innovationsprozesse, Cluster-Evolution, Outdoor-Industrie

Résumé: Le rôle de la culture, de la consommation et de la communauté dans le développement des clusters: le cas de l'industrie des sports et des activités de plein air de Portland, Oregon (USA)

Au cours des dernières années, la géographie économique a commencé à prendre en compte le rôle des utilisateurs et des consommateurs dans les processus d'innovation. Les utilisateurs et consommateurs sont ainsi considérés comme des «acteurs réfléchissants» (Grabher, Ibert \& Flohr 2008) qui influencent profondément le développement des produits et des services. Toutefois, cette littérature néglige le rôle des utilisateurs et des consommateurs dans un contexte régional déterminé et leurs influences sur le développement d'un cluster. En se basant sur l'exemple de l'industrie du sport et des activités de plein air à Portland, Oregon (USA), cet article analyse l'importance des attributs spécifiquement culturels, de consommation et de communauté dans une région nord-américaine et démontre leur influence sur la création et le développement d'un cluster.

Mots-clés: processus d'innovation basé sur les utilisateurs, émergence de clusters, industrie des sports et activités de plein air

Prof. Dr. Heike Mayer, Institute of Geography, University of Bern, Hallerstrasse 12, CH-3012 Bern, Switzerland.

Joseph Cortright, Impresa Consulting, 1424 NE Knott Street, Portland, OR 97212, USA.

e-mail:

mayer@giub.unibe.ch

jcortright@impresaconsulting.com

Manuskripteingang/received/manuscrit reçu le 7.6.2011

Annahme zum Druck/accepted for publication/accepté pour publication: 23.1 .2012 